\title{
Soviet Union on the Seine: Kontinent, Sintaksis, and the Social Life of Émigré Journals
}

\section{PHILIP GLEISSNER}

\begin{abstract}
Maria Rozanova: Having arrived to the West, we, the third emigration, built a world that is absolutely the same as the one we had left behind. The same as the one we were once fighting so fiercely. ... The only thing is - we can't build our own Lubyanka. But I think that is only because ...

AndRei Sinyavsky: ....Because we live in a free country.

MARIA ROZANOVA: Because we live in a country where the government wouldn't allow us to do so. But if they did, we would do it immediately. Immediately.
\end{abstract}

John Glad, interview with Rozanova and Sinyavsky, 1986

\begin{abstract}
$\mathrm{W}$
ith the arrival of the so-called third-wave emigration-Soviet citizens who were allowed to leave for the West between the late 1960s and the mid-1980s-numerous new journals appeared on the stage of Russian émigré culture. Since the Thaw, the "literaryartistic and socio-political" or "thick" journals had again come to function as a central institution of the Soviet intelligentsia. Through journals like Kontinent and Sintaksis, the third wave paradoxically recreated in the West two main characteristics of what can be considered a late Soviet mode of cultural production. First, the third wave persistently relied on thick journals as the privileged means for the politicized organization and distribution of literature. This choice is by no means a self-evident one in the environment of Paris, Frankfurt, or New York. ${ }^{1}$ Second, third-wave intellectuals quickly reinstituted the

I would like to thank Natalia Ermolaev, Devin Fore, Neringa Klumbyte, Serguei Oushakine, and the two anonymous reviewers from The Russian Review for their critique and suggestions. I also want to thank the staff at the Center for Digital Humanities at Princeton University for their support and critical comments regarding the Digital Emigre dataset.

${ }^{1}$ As competing models for the circulation of literary texts, one might consider alternative publishing economies organized around books, weeklies, almanacs, and especially the preexisting institutions of the Russian emigration - periodicals like Grani or Posev or even the Ardis publishing house, run by Carl and Ellendea Proffer in Ann Arbor, Michigan. While these publications had accommodated texts by dissidents before their arrival to the West, they were now neglected.
\end{abstract}

The Russian Review 77 (July 2018): 446-69

Copyright 2018 The Russian Review 
antagonistic binary structure that governed the relationship between the dissident Soviet intelligentsia and state-sanctioned media, a competitive yet highly interdependent struggle between monopolistic mass institutions and the subversive tactics of a minority.

In the Soviet Union, Vladimir Maximov, Maria Rozanova, and her husband Andrei Sinyavsky, who later became the editors of Kontinent and Sintaksis, respectively, famously contributed to the dissident culture of clandestine literary production and circulation. However, the official thick journals were central to their lives even before their departure to the West to an extent that may seem paradoxical. Maximov actively published in the journal Oktiabr' and briefly served on its editorial team from 1967 to 1968 . Sinyavsky printed respectable literary criticism in Novyi mir, already then using the journal as a medium for the provocative negotiation of literary life that was later fully developed in Sintaksis. Even after Sinyavsky's arrest in 1965, Rozanova continued to publish in the Soviet journal Dekorativnoe iskusstvo pieces that were developed in dialogue with Sinyavsky, proving thereby the ability of Soviet journals to accommodate and absorb contradictory ideas. ${ }^{2}$

The thick journal was thus one of the constitutive components of Soviet (official as well as dissident) intellectual habitus, of their "systems of durable, transposable dispositions, structured structures predisposed to function as structuring structures, that is, as principles of the objectively 'regulated' and 'regular' without in any way being the product of obedience to rules." ${ }^{3}$ Founding Kontinent in Paris in 1974 was quite possibly Maximov's most successful contribution to the persistence of the model of Soviet literary mass journals, while Rozanova's and Sinyavsky's Sintaksis continued their project of staging aesthetic disagreement against a monolithic mass culture. While the debates of the third wave often circled around very concrete mutual accusations of "Sovietness," ranging from the reproduction of totalitarian cultural hierarchies to accusations of collaboration with the KGB, introducing Bourdieu's concept of habitus allows a more critical revision of 1980s émigré culture. It emphasizes that matters of taste and cultural practice are not as much deliberate choices toward a distinct end, but much rather a set of deeply engrained and barely avoidable proclivities. Displaced into the context of the émigré scene, the habitus built on a Soviet experience, dissident or other, both reproduces familiar structures and creates new tensions vis-à-vis the new environment.

This article revisits the journals in order to trace the mechanisms governing the intellectual life of the late Soviet diaspora. It does not focus so much on the rhetoric of the texts presented in the journals - their debates and arguments-but traces how journals functioned as central forces in the social organization of cultural life of the third wave. Sintaksis and Kontinent, the two Paris-based journals that I analyze here, display a distinctly Soviet mode of literary practice — between dissidence and conformism, uniformity and

\footnotetext{
${ }^{2}$ Her contributions were developed through a close intellectual exchange with Sinyavsky, partly in their correspondence. Especially her article "Fantasticheskii realizm: Razmyshleniia o real'nom i fantasticheskom v narodnom iskusstve," Dekorativnoe iskusstvo SSSR, 1967, no. 3:2-6, is worth mentioning here, since it continues a line of thought about fantastic realism that Sinyavsky had begun in his articles in Novyi mir. As Rozanova phrases it, her name even came to serve as Sinyavsky's pseudonym during his prison camp sentence. See Mariia Rozanova, "Neskol'ko slov ot adresata etikh pisem," in Andrei Siniavskii, 127 Pisem o liubvi (Moscow, 2004), 15.

${ }^{3}$ Pierre Bourdieu, Outline of a Theory of Practice (Cambridge, England, 1977), 72.
} 
diversity - that sets them apart from earlier generations of émigrés and their periodicals. On the one hand, these origins become productive frames of reference for the journals; at the same time, they inhibit the occurrence of the independent literary life that their initiators may have been seeking.

Kontinent soon became a hub of publication for émigré intellectuals and dissidents based on both sides of the Iron Curtain. Sintaksis may appear in many ways as the counterpart to Maximov's project, representing a new kind of dissenting voice. Sinyavsky and Rozanova, the de facto editor, ran the journal out of the family's home in a suburb of Paris beginning in 1978. The story of these two publications has gone down in literary and cultural historical scholarship as a narrative of an antagonistic confrontation - if not between conservative and progressive ideologies, than at least between relative intellectual openness and opinionative (and aesthetic) restriction. Scholarship on Kontinent and Sintaksis has traditionally localized these positions in the writings of editors and accounts of their personal conflicts on the one hand, and in close readings of select contributions to the publications on the other. ${ }^{4}$

Both kinds of analysis are reductive in their own way and cannot represent the journals holistically. Every judgment based on personal or textual incidents can easily be refuted, and within the vast corpora provided by some twenty years of the two publications one can find for each journal a democratic answer to an authoritarian argument, a realist counterpart to postmodern art, and so forth. What this historical-literary approach that focuses on the journals as "containers of discrete bits of information" cannot take into account is the role that periodicals took as objects and actors in a living intellectual environment. ${ }^{5}$

This article is inspired by recent work in Anglo-American periodical studies that has attempted to reassess journal culture in a way that can factor in the complex material and social life of periodical publications, reflecting the plurality of voices and texts that they contain. Periodicals function as social institutions within a system of distinct mechanisms of cultural production. This emphasis on the "social life" of journals is informed by Bruno Latour's notion of the "social," which argues that cultural impact is a result of interactions and ties between actors - be it people (editors, readers, authors) or, here, objects and documents (the journals themselves).

Digital approaches to the text reveal, and allow us to reevaluate, these internal social dynamics of the journal. By compiling a dataset from the digitized and machine-readable versions of Sintaksis and Kontinent and querying and visualizing this data, common narratives about the journals can be challenged. ${ }^{6}$ Looking at the social life immanent in

${ }^{4}$ For a variety of interpretations of what animated Sintaksis and Kontinent see Olga Matich and Michael Henry Heim, eds., The Third Wave: Russian Literature in Emigration. (Ann Arbor, 1984), 102; Catherine Theimer Nepomnyashchy, "The Alter Ego: Émigré Literary Criticism from World War II to the End of the Soviet Union," in A History of Russian Literary Theory and Criticism: The Soviet Age and Beyond, ed. E. A Dobrenko and Galin Tihanov (Pittsburgh, 2011), 280; Eugenie Markesinis, Andrei Sinyavsky: A Hero of His Time? (Boston, 2013), 129; Wolfgang Kasack, “'Kontinent' - Kritische Durchsicht einer jungen Zeitschrift," Osteuropa 26:12 (1976): 1057; and E. Skarlygina, "Literaturnyi protsess v Rossii 1970-1980-kh godov i zhurnaly russkoi emigratsii," Vestnik moskovskogo universiteta. Seriia 10. Zhurnalistika, 2012, no. 2:93.

${ }^{5}$ Sean Latham and Robert Scholes, "The Rise of Periodical Studies," PMLA 121, no. 2 (2006): 517-31.

${ }^{6}$ For further documentation on the compilation of the Sintaksis-Kontinent dataset, as well as the data itself, refer to "Digital Émigré - Compiling a Small Data Set for the Study of Russian Periodicals in Emigration" on my blog at www.philipgleissner.com/digitalemigre. 
these data allows us to "theorize non-hierarchical agency," as it can evade the framing of periodicals in terms of canonical texts and instead represents social actors more indiscriminately. ${ }^{7}$ By reconciling these observations from a distanced perspective with an analysis of the ways editorial policies were expressed and individual debates were organized within and across journals, I will show that Kontinent and Sintaksis stood in a distinct kind of relationship. This relationship is characteristic of the intellectual economy of what I call the Soviet Union on the Seine - a cultural space that has ideologically freed itself from the Soviet state, but where the organizational principles and the configuration of relations of Soviet culture persist. As such, the journals exist in a system that cannot be exhaustively described as governed by the antagonism between the dogmatically monolithic closedness attributed to Kontinent and the pluralism of Sintaksis.

\section{A NEW CONTINENT AND STILL NOWHERE TO PUBLISH}

"Literature cannot be a means of enriching individuals or groups: it cannot, in fact, be an individual undertaking, independent of the common cause," states Lenin in his 1905 "Party Organization and Party Literature." A foundational text with regard to the organization of the Soviet periodical press, it outlines a structural model of the mass journal that was ultimately also exported by Maximov with Kontinent. As I will show in the following, the journal can therefore be called strictly anti-Soviet only on the level of its explicitly stated ideology. This analysis will provide a new perspective on Rozanova's and Sinyavsky's rejection of Maximov's project and their quest for a new publishing platform.

No other than Aleksandr Solzhenitsyn provided a letter of endorsement for Maximov's project, originally addressed to its German publisher, then reprinted next to the foreword to the inaugural 1974 issue of Kontinent, which stated that "the aim of our journal is not only political polemics with totalitarianism, but most of all to oppose it - this militant totalitarianism - with the united creative power of Eastern Europe's literature and spiritual thought." While for Lenin the party periodical had to unite everyone for the cause of the proletariat, Maximov's journal sought to bring together all anti-Soviet voices. While the ideological key has changed, in both cases the journal serves the purpose of overcoming an individualistic model of literature in order to build a politically powerful organization (fig. 1).

But how would a journal published by dissidents post emigration have an actual political impact on the Soviet Union, as implied by Solzhenitsyn? It was read broadly in Paris and Frankfurt, but its reach within Russia was sporadic and presumably limited to the urban

\footnotetext{
${ }^{7}$ Wesley Beal, "Theorizing Connectivity: Modernism and the Network Narrative," Digital Humanities Quarterly 5, no. 2 (2011): 3.

${ }^{8}$ Vladimir Il'ich Lenin, "Party Organization and Party Literature," in his Collected Works, vol. 10 (Moscow, 1972), 45

9“'Ot redaktsii," Kontinent 1 (1974): 4. The foreword also establishes a connection to Herzen's émigré journal Kolokol. Moreover, the successful Polish émigré journal Kultura, and especially its editor Jerzy Giedroyc, seems to have served as a model for Maximov. See Karolina Ziolo-Puzuk, "Contact Beyond Borders and Historical Problems: Kultura, Russian Emigration, and Polish Opposition," in Samizdat, Tamizdat, and Beyond: Transnational Media during and after Socialism, ed. Friederike Kind-Kovacs and Jessie Labov (New York, 2015), 92-104.
} 
centers. The self-evidently assumed idea of the periodical as an organic component of political organization is rooted deeply in the Soviet journal habitus. "If we fail, and as long as we fail, to combine our efforts to influence the people and the government by means of the printed word, it will be utopian to think of combining other means, more complex, more difficult, but also more decisive, for exerting influence," explains Lenin in his theory of the party press. The function of the party journal lies not merely in agitation and propaganda, but in its role as a collective organizer, an organizer of voices that appear nonexistent, when "those who are able and ready to make exposures have no tribune from which to speak." ${ }^{10}$ Such an approach would also explain the self-evidence with which Kontinent assumed its political significance. Through its emergence, the journal organizes a social space and incorporates the people involved in and surrounding the periodical as a sociopolitical force.
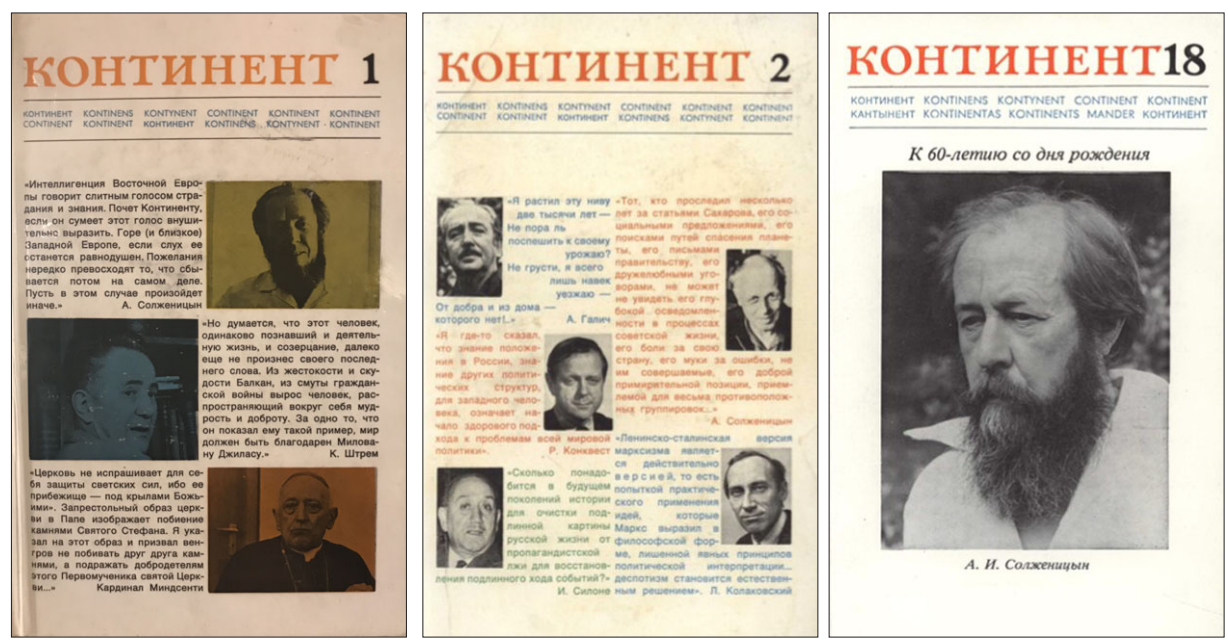

FIG. 1 Covers of Kontinent 1 (1974), 2 (1975), and 18 (1978).

In the case of Kontinent, this also holds true for the way Maximov succeeded in attracting Sinyavsky, despite the fact that the ideological program of the project as stated by Solzhenitsyn's letter probably was not quite in alignment with Sinyavsky's own ideological and aesthetic views. Sinyavsky was listed as one of the journal's affiliates and contributed, under the pseudonym Abram Tertz, his "Literary Process in Russia" to the first issue. ${ }^{11}$

While Sinyavsky's writing in Kontinent attracted some scorn from within the Russian emigration, the first loud critique of the journal came from a somewhat unexpected sidenamely, the West German intellectual left. They took issue with a seemingly peripheral problem: the publisher, Wolf Jobst Siedler, and his publishing house Ullstein. A subsidiary

\footnotetext{
${ }^{10}$ Lenin, "Where to Begin," Collected Works 5:21.

${ }^{11}$ Sinyavsky's analysis of Soviet literary life gained some scandalous attention due to its reference to Russia as a bitch ("Rossiia-Mat', Rossiia-Suka"). It also marks Sinyavsky's first statement in a lasting polemic with the aesthetic doctrine of realism that came to antagonize much of the Russian diaspora, most of all Aleksandr Solzhenitsyn. See Abram Terts, "Literaturnyi protsess v Rossii," Kontinent 1 (1974): 183; and Walter F. Kolonosky, Literary Insinuations: Sorting out Sinyavsky's Irreverence (Lanham, 2003), 131 f.
} 
of the highly controversial German publisher Axel Springer, Ullstein was perceived by the German left as complicit in the expansion of Springer's conservative media empire, thus posing a threat to freedom of press and democratic values.

In mid-October 1974, the German author Günter Grass publicly addressed Sinyavsky and Solzhenitsyn (tellingly not Maximov, who was not perceived as a key figure by Western intellectuals), reprimanding them for their poor choice of allies:

As authors in the journal Kontinent you will be collaborating with a certain power empire, famous under the name of the Springer-Konzern, whose reactionary intolerance is an expression of the same mentality which, under different ideological markings, forced you in the Soviet Union to protest and to resist.

Grass explains that the Springer Group and especially its tabloid Bild are based on "falsification of information according to doctrinaire opinions, demonization of political opponents, appeal to the latent violence in the so-called silent majority." The Western intellectual's implicit demand for loyalty may have felt familiar for Sinyavsky, whose infamous trial was triggered by the fact that he had published his works in the West, thereby choosing the ideological enemy as an institutional ally. ${ }^{12}$

Sinyavsky harshly defended his intellectual independence. Calling Grass's comparison of Springer and the Soviet state "simply scandalous," he concludes: "Your point of reference is a pile of opinionated newspaper clippings that you found unjustifiable. But our point of reference is a mountain of corpses-among them writers and poets." Sinyavsky's juxtaposition of state terror and a few "opinionated newspaper clippings" expresses a strong disinterest in the ideological cleavages of West Germany, where leftist intellectuals were convinced that Springer threatened the stability of the democratic order of the state after World War II. He emphasizes the complete editorial independence that had been promised by Ullstein, concluding that "there are no guide-lines, and we shall write as we please. Or can it be that you actually believe that we can be made to dance to somebody's tune?"13

Suspicion toward Kontinent persisted in German media, where first-generation émigré Andrey Razumovsky followed up with another attack in Frankfurter Allgemeine Zeitung in 1977, triangulating journalistic malpractice between Maximov's Kontinent, the dreaded German Bildzeitung, and the totalitarian state. Relying on the observations of a former member of the journal's board, Razumovsky alleges that "in Kontinent there are no discussions."

In Kontinent no other opinion is given the word other than what is pleasant to Maximov. Kontinent ... has become a journal of messiahs. ... And in a certain way it is governed by the same state of affairs that Vladimir Maximov had experienced in Moscow-albeit in reverse this time. ${ }^{14}$

\footnotetext{
12“Günter Grass \& Andrei Sinyavsky," Encounter, no. 12 (1974): 94 (originally in Frankfurter Allgemeine Zeitung (October 14, 1974). On the harshness of Grass's demand see page 94 of Encounter.

${ }^{13}$ Ibid., 95.

${ }^{14}$ Andreas Razumovsky, “'Es ist ein Unglück, daß sie das noch nicht begriffen haben': Eine kritische Untersuchung des 'Kontinent,"” Frankfurter Allgemeine Zeitung (December 17, 1977).
} 
In his description of what he dismissively called a new Moscow on the Seine, supposedly characterized by Soviet methods of censorship and totalitarian discourse, Razumovsky barely differentiates between chief editor, editorial staff, authors and individual contributions, and the journal at large. Viktor Nekrasov, deputy editor of Kontinent, protests against this reductive depiction in another letter to the German newspaper. ${ }^{15}$ Razumovsky's accusations of Sovietness cannot be called particularly original in the Cold War environment, where mutual suspicion of collaboration with the KGB and sympathizing with the Soviet Union were omnipresent rhetorical clichés (albeit ones that had, at times, devastating consequences).

But Razumovsky's exposé can also be seen as an expression of a strong anxiety over the emergence of a new generation of participants in the émigré literary field. It is a generation that had grown up under Soviet socialism, internalizing its language, cultural forms, and social behaviors. These circumstances had shaped the kind of habitus that the third wave could not simply dispose of upon their arrival in the West. Razumovsky's uneasiness may have been caused by the observation of these alien structures that also brought forth Kontinent as a mass journal ultimately in the tradition of Lenin's periodicals. For an émigré of the earlier generation unprepared to respond to this kind of institution, a personal attack on Maximov may have appeared the only option.

However, this way of forming arguments about any periodical remains vulnerable. Selectivity becomes the ultimate counterargument to disarm all claims about periodical publications-from Sinyavsky's “opinionated clippings" of Grass to Nekrasov's reference to Razumovsky's ignorance toward the best contributions in Kontinent. The argumentative conundrum persists as a methodological problem in the scholarly discussion of journals, where the case study of contributions and individual actors is not scalable and does not lead to a viable argument about the journal as such.

Here, bibliographical data can allow for a different point of entry. If Kontinent were indeed as selective and exclusive as is often claimed, it should have rejected in its editorial practice authors who were in line with its alleged ideological counterpart. Moreover, the contributors of Kontinent should have refused their cooperation with Rozanova's journal out of loyalty. In a network between journals and authors, where the periodical functions like an "object proceeding through a system of people," organizing individuals like magnets would arrange iron pieces, mutually exclusive circles should form around the two journals. ${ }^{16}$

Figure 2 represents as white nodes all those authors who were published in either Sintaksis, the central node on the right, or Kontinent, the central node on the left, at least twice between 1978 and 1992. The graph shows how both journals have their distinct communities. But it also shows that there is a significant community of shared authors. Since the graph only includes authors published after 1978, it does not include the group of authors who broke away from Kontinent with the foundation of Sintaksis - such as Sinyavsky and Igor' Golomshtok, Sinyavsky's friend of many years.

\footnotetext{
${ }^{15}$ E. Skarlygina, ed., "Iz arkhiva zhurnala 'Kontinent,"” Voprosy literatury, 2007, no. 2, http:// magazines.russ.ru/voplit/2007/2/ko18.html (last accessed February 4, 2018).

${ }^{16}$ Sergei Tret'iakov, "The Biography of the Object," October 118 (2006): 62.
} 
The visualization of the journals' data challenges assumptions about exclusivity and monopolistic editorial policies. From this position, a critique like Razumovsky's represents only one (selective) reading of the journal's text, one that is explicitly disinterested in the field between the journals that would imply porous borders and exchange rather than censorship and restriction. Other readers of the time may have realized the synthetic text of the journals in many other ways, choosing to pay attention to other authors and contributions (fig. 3).

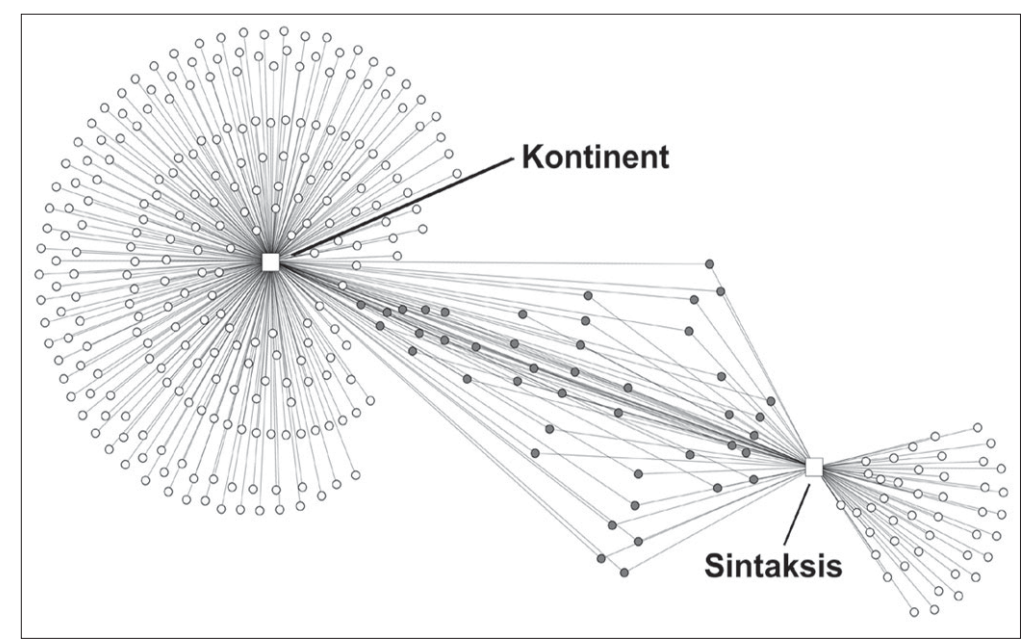

FIG. 2 Contributors to Kontinent and Sintaksis between 1978 and 1992.

Every circle represents an author who contributed at least two times to one or either of the journals (represented by the two central nodes).

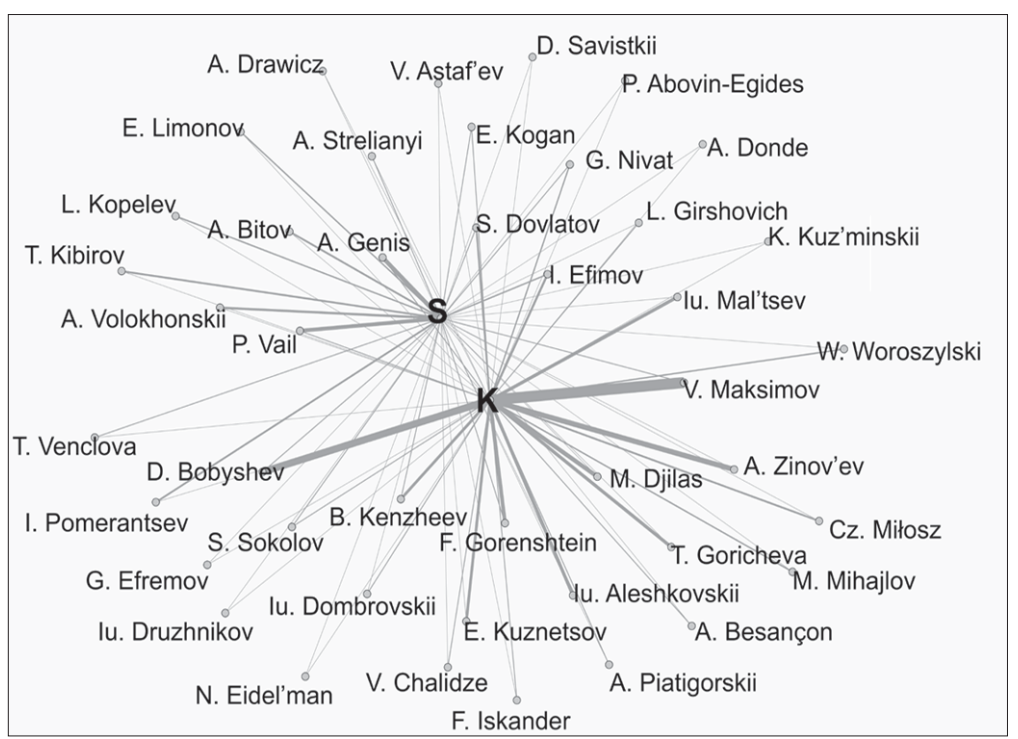

FIG. 3 Contributors to both Kontinent and Sintaksis between 1978 and 1992. 
Many of the authors that are now considered classics of the 1980s, and central figures of the third-wave émigré literary environment, can be located specifically in this field between the two journals; among them are Igor' Pomerantsev, Alexandr Genis, Petr Vail', Sasha Sokolov, Igor' Efimov, Sergei Dovlatov, Eduard Limonov, and Tomas Venclova, who was even enlisted in Sintaksis's "League of Supporters." From the methodological perspective of periodical studies, this view on the journals through the lens of their bibliographical data can provide new angles to the study of Kontinent and Sintaksis. This lens can serve as a tool pointing directly to individual cases that can refute claims of Kontinent's dogmatic conservatism - such as the scandal-oriented Eduard Limonov or liberal Mihajlo Mihajlov.

In 1980, Kontinent printed a selection of Limonov's poetry with an introduction by the editor Natal'ia Gorbanevskaia. The example of Mihajlov shows how certain ideological positions and political arguments could very well be accommodated by both Sintaksis and Kontinent alike. Mihajlo Mihajlov, an avid critic of the Russian political exceptionalism postulated by Solzhenitsyn, was published in both journals, although he belonged to the editorial board of the Kontinent until 1984. Mihajlov's article in a 1981 issue of the journal of the allegedly ideologically monolithic Maximov is a critique of what he sees as the dangerous fusion of national ideas and religion that would inevitably lead into a renewed Russian authoritarianism. It is an arduous defense of pluralism and individual freedom as the central pillars of a democratic society. However, the editors of Kontinent prefaced the article in a peculiar way, expressing disagreement from an editorial standpoint. In other cases, similar pieces were allowed to stand without such commentary. For instance, Valerii Chalidze's "On Some Tendencies in Émigré Journalism" was printed a year earlier in Kontinent. The polemical style of his commentary on the idea of Russian exceptionalism may appear more reminiscent of Sintaksis, where he published as well, but it could also be accommodated by Kontinent: "So what is democracy?-The right of everyone to have a share in the government of their country. So apparently the Russians cannot be given this right? They can't manage? You see, we were afraid of nationalism as the claim of national superiority, but we are being presented with a thesis of national inferiority!' 17

The position of the authors in this graph is randomly assigned. However, the thickness of their connections to the journals expresses the strength of the connection between contributors and journals. The thicker the line, the more often the author contributed. Most authors have a stronger connection to one of the two journals. The number of authors who published to an approximately equal extent in both journals is very small. We can read Vail' eight times in Sintaksis, but only two times in Kontinent. Aleksandr Zinov'ev was featured eleven times in Kontinent, but only once in Sintaksis. As the social tie to one journal is confirmed through publishing in it more often than in the other, authors become more closely affiliated with that specific community. However, this belonging would make publication in the other journal even more significant, proving the existence of a certain degree of openness in this system.

The question remains then, how Kontinent came to be perceived as ideologically impenetrable despite these connections. Rozanova phrased the problem in a peculiar way

${ }^{17}$ Kontinent 23 (1980): 171. See also ibid. 25 (1980) and 28 (1981). 
at a May 1981 summit of Russian émigré authors in Los Angeles, thereby providing us with a cue:

Our poor little journal Sintaksis appeared in a minute of despair, a minute when suddenly, in the third or fourth year in emigration, it became clear that one of my favorite authors ... Abram Tertz, had nowhere to publish. Again, nowhere to publish. ... And that's when I said: "Listen, Sinyavsky, here, there is freedom. If there is no place for you to publish, let's found our own journal."

As the protocols of debates in Los Angeles have it, Nekrasov immediately challenged Rozanova's claims. All personal animosities aside, he emphasizes, Maximov would unconditionally publish the work of Sinyavsky/Tertz in Kontinent.$^{18}$ Similarly, in an interview I conducted with Rozanova on August 8, 2013, in Fontenay-aux-Roses, she foregrounded the break from Kontinent as motivated by the aversion that she and Sinyavsky had developed for Maximov's journal already at a fairly early point, rather than the editor's unwillingness to accept their texts.

The personal feud between Maximov and Sinyavsky is well known and documented. ${ }^{19}$ But something other than just a strong mutual animosity stands at the core of Rozanova's 1981 statement about journals, which will be very important for the understanding of both Sintaksis and Kontinent as shaped by a Soviet institutional heritage and editorial realities. "Nowhere to publish" does not necessarily refer to restricted access, for "who would believe" that Sinyavsky, to use his own words, could "be made to dance to somebody's tune"? After all, Sinyavsky and Rozanova had developed impressive skills for literary activity even under the restrictions imposed by the Soviet regime after Sinyavsky's arrest—-be it through their above-mentioned publications in Soviet journals or the intellectual exchange hidden in their prison camp correspondence, which later provided the material for Sinyavsky's books Strolls with Pushkin and A Voice from the Chorus. ${ }^{20}$

However, from their own experience Rozanova and Sinyavsky must have been aware that by immersing themselves in the larger community of the mass journal they would become invisible; this was diametrically opposed to their aesthetic program of provocation and scandal. And herein lies the problem of Kontinent, which by uniting huge numbers of intellectuals created a situation of invisibility that Rozanova sought to disrupt. In fact, it was fairly easy to go unnoticed in Maximov's journal, where around 250 authors published in the 18 issues between 1974 and 1978 alone, and about 850 authors altogether published between 1974 and 1992 .

This united front of diverse voices, including émigré authors, Western intellectuals, and Soviet and other Eastern European dissidents, made Kontinent a seemingly powerful social organizer in the sense of Lenin's party press and a credible institution in the sense of Western political activism - if not vis-à-vis the Soviet state, where its dissemination was

${ }^{18}$ Matich and Heim, The Third Wave, 175.

${ }^{19} \mathrm{Glad}$, "Antizapadnichestvo v sovremennykh usloviiakh - eto antikul'tura" (interview with Andrei Sinyavsky and Maria Rozanova), Vremia i my, no. 88 (1986).

${ }^{20}$ Abram Terts, Golos iz khora (London, 1973); idem, Progulki s Pushkinym (London, 1975). When an excerpt from Progulki s Pushkinym was published for the first time in the Soviet journal Oktiabr' in 1989, it immediately provoked a scdandalous response among readers and critics. 
naturally limited, then at least with regard to audiences in the West. Maximov's editing strategy was oriented toward the "increased consumption or awareness of a given work," described as the "amplification" function of publishing. ${ }^{21}$ However, in the journal, it seems this kind of amplification stands in an inverse relationship to the visibility of the individual text. Long lists of names, including an ever-growing number of nominal members of the editorial board, serve to accumulate a kind of symbolic capital in the journal that offers itself to support ideological positions.

The list of prestigious names allows the rather unknown Maximov to position himself as a credible organizer within the literary field, engaging with the ways it already had assigned positions to other Russian intellectuals. ${ }^{22}$ As Bourdieu suggests, the literary field can be understood as a space, where "each position is objectively defined by its objective relationship with other positions." ${ }^{23}$ By aggregating names with high prestige (or, symbolic capital) attached to them, Maximov thus generates a position in the field for his journal and himself, co-opting to a certain extent all other positions that he manages to attach to himself.

The extent to which this practice of accumulating symbolic capital also bears the seal of the publisher is evident in an interview published in Kontinent, where the German media tycoon Axel Springer himself explains his concept of media that so terrified the German left: "the printed word in the hands of free entrepreneurs has a chance to impact only when it is carried out by large scale technical and economical enterprises." ${ }^{24}$ It is easy to see how critics like Grass, under the relatively recent experience of the Nazi state, would draw a comparison between this kind of tendency toward monopolization of the press by a large capitalist enterprise and the Gleichschaltung of media in a totalitarian state. ${ }^{25}$ But as the analysis above shows, the inertia of Soviet structures of publishing — both Lenin's ideology and late socialist realities - is qualitatively different from Springer's monopolistic structures (although the latter did provide the economic basis for the existence of the former). Similarly, the ways Rozanova and Sinyavsky encounter it can only be understood against the background of a distinct Russian and Soviet cultural heritage.

\section{MARIA ROZANOVA'S SALON}

How can one reclaim a discursive space that is controlled by a dominant other, be it a monopolistic media enterprise or a periodical built after the model of Lenin's party publishing, a space where there is "nowhere to publish"? The intuitive answer would be to invert its laws, to withdraw into an intimate realm of selective affinities. Paradoxically, exclusivity becomes the liberating move through which Sintaksis claims to counter the problem of a mass journal that is so often accused of exclusivity in its own right. This is

\footnotetext{
${ }^{21}$ Michael Bhaskar, The Content Machine: Towards a Theory of Publishing from the Printing Press to the Digital Network (London, 2013), 115.

${ }^{22}$ Solzhenitsyn speaks about this problematic position in his "Ugodilo zernyshko promezh dvukh zhernovov: Ocherki izgnaniia. Chast' pervaia," Novyi mir, 1989, no. 9.

${ }^{23}$ Pierre Bourdieu, The Rules of Art? Genesis and Structure of the Literary Field, trans. Susan Emanuel. (Stanford, 1996), 231.

${ }^{24}$ Kontinent 10 (1976): 420.

${ }^{25}$ Similarly, Andreas Razumovsky's attack on Kontinent can be understood in light of the experience of German totalitarianism, which he presents as an ultimate insight (“"Es Ist Ein Unglück”").
} 
expressed in editorial statements like the response to a complaint by a rejected author: "With a uniformly homogeneous distribution of texts vanishes the face of the journal, and the author himself fades into an undifferentiated environment." ${ }^{26}$ Rozanova claims to defend her journal against masses of submissions. Of course, it remains to be established whether her home, the address of which was published openly in every issue, was really flooded with texts for publication. Regardless, the editorial statement serves to inform the readers that a distinct model of publishing is pursued here. It responds to the tradeoff between the "unlimited distributional capacity" of the journal described above and the limited resource of readers' attention that would grant visibility to one author among others. This model of a journal highlights the significance of filtering that "comes before amplification"-a selection process that can preserve the individual character of a community. ${ }^{27}$ The following section analyses how Rozanova pursues this supposedly liberating tactic of selectivity and it uncovers the risks attached to this tactic.

сути, единствениая реальность ? А так назьваемая действительность это уже сон или, если угодио, надстройка над искусством. И без искусства, вне искусства действительность сама по себе юичего не значит и ничего не стоит. Не было бы никакой действительности, если бы не было искусства. И поэтому в виде реликтов или, как говорит советская власть, в виде диверсий, идеологических диверсий, противозаконно и преступно, искусство время от времени троявляется и дает о себе знать. Как язычки пламени из-под земли. И как художественная первооснова жизни. Как напоминание о том, что такое на самом деле история и что такое природа.

Вот один из возможных аспектов и одно из частныг значений советского художественного диссидентства.

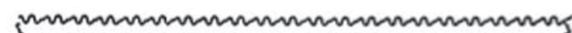
П ПОКУПАЙЕ РУССКИЕ ГАЗЕТЫ \} И Ж У РНА ЛЫ:

ВЕСТнИК РХД (Париж-Нью-Йорк-Москва), ВРЕМЯ И МЫ (Тель-Авив), ГОЛОС ЗАРУ-

БЕЖБЯ (Мюнхен), ГРАНИ (Франкфурт-на-

Майне), ДВАдЦАТЬ дВА (Тель-Авив),

КОВЧЕГ (Париж), КОНТИНЕНТ, НАША

СTPAHA (Буэнос-Айрес), НОВОЕ РУССКОЕ

СЛОВО (Нью-Йорк), НОВЫЙ ЖУРНАЛ

(Нью-Йорк), ПОСЕВ (Франкфурт-на-Майне),

РУССКАЯ МЫСЛЬ (Париж), РУССКОЕ

ВОЗРОЖДЕНИЕ (Париж-Москва-Нью Йорк),

СИОН (Тель-Авив), ТРЕТЬЯ ВОЛНА (Фран-

ция), ЧАСОВОЙ (Бргоссель), ЭХО (Париж).

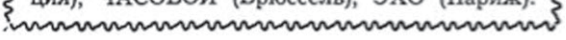

119

FIG. 4 Sintaksis 2 (1978).
With this focus on the formation of distinct communities allowing legibility of aesthetic taste and political positions, Sintaksis can become a part of a larger landscape of periodicals, an institution of an envisioned public sphere. Such ideals of cultural and political debate can be traced in the first few issues of Sintaksisin the section "Our Mail," which featured editorial statements and polemical responses to the letters of readers. The first two issues featured a short section encouraging the readers to "buy Russian newspapers and journals," including publications of the first and second generations of Russian emigrants: the older Vestnik russkogo khristianskogo dvizheniia, Grani, Novoe russkoe slovo, along with third-wave journals like Kontinent, Dvadtsat' dva, Ekho, and so on. In the second issue Rozanova quotes objections from readers' letters: "On what grounds do you propagate white guardist and monarchist publications such as The

Sentry?" and "How could you put the names of Zion and Russian Revival next to each other in your advertisement for Russian journals?" The editor's response is ironically simple: "In alphabetical order: first 'Russian' then 'Zion.' We do not propagate, but recommend that our readers read and acquaint themselves with various opinions and directions of

\footnotetext{
${ }^{26}$ Sintaksis 4 (1979): 157.

${ }^{27}$ Bhaskar, Content Machine, 108, 110.
} 
thought — regardless whether they perceive them as close or hostile." ${ }^{28}$ These editorial interventions aim to idealistically bridge the communities of intellectual producers and consumers. While both sides may be separate, informed readers are still envisioned as an active and necessary interlocutor in order for critical debate to function. ${ }^{29}$

It is important to note that many of the periodicals on Rozanova's reading list are literary rather than political in nature. But in the traditional genre of the "literary-artistic and socio-political journal," the aesthetic, social, and political have a long-standing tradition of a symbiotic relationship. This gains even greater significance with the "excessive politicization of the third wave," a group largely lacking access to institutions that would have offered themselves as an outlet for political agendas and their active implementation. ${ }^{30}$

This symbiotic relationship between the aesthetic, the political, and also the economical and social are part of the distinct generic heritage of the Russian thick journal that can be understood as a continuation of the literary salon. As Mark Aronson and Solomon Reiser show in their study of nineteenth-century salon culture, its social institutions provided "on the one hand the connection between writer and reader, on the other hand between the members of one literary party." This function, they argue, was not discontinued with the powerful takeover of the culture of mass journals in the mid-nineteenth century; rather, it was incorporated as one of the central features of this culture. ${ }^{31}$

Approached from this direction, the aesthetic practice of journals is one of the major sites of the literary environment (literaturnyi byt), conceptualized first in Boris Eikhenbaum's "curious attempt at an 'immanent' sociology" of literature. ${ }^{32}$ His reorientation of inquiry toward literature as social practice - not "how to write," but "how to be a writer"-finds direct application in Aronson's and Reiser's study of the salon as a social space where authors encounter other authors, and authors encounter their readers. ${ }^{33}$ The editor, much like the host of the salon, becomes the facilitator of the literary environment, moderating debates and social relations alike.

While this model of the salon is commonly associated with the nineteenth-century bourgeois elites, it reoccurs on a functional level in Soviet culture in the shape of the workers' club that is both a physical space and as well as an intellectual institution facilitating a similar kind of cultural practice. The early Soviet artists Alexander Rodchenko and Varvara Stepanova, for example, tried to develop a new kind of communal intellectual life through their architectural projects. They envisioned the production and reception of periodicals as an intertwined performance of the "living newspaper" by large participating audiences in workers' clubs, which were designed in a way that would enforce intellectual life as a

\footnotetext{
${ }^{28}$ Sinktaksis 2 (1978): 130.

${ }^{29}$ The appeal to the readers' involvement in critical debate, which the suggestion to read broadly implies, echoes Habermas's "Kunstrichter," which assigns to the journal reader the role of art critic. See Habermas, The Structural Transformation of the Public Sphere: An Inquiry into a Category of Bourgeois Society, trans. Thomas Burger (Cambridge, MA, 1989), 41.

${ }^{30}$ Skarlygina, "Tret'ia russkaia emigratsiia v kontekste otechestvennoi kul'tury 1960-1980-kh godov i kul'tury russkogo zarubezh'ia," Vestnik Moskovskogo Universiteta, Seriia 10, Zhurnalistika, no. 1 (2009): 129.

${ }^{31}$ Mark Aronson and Solomon Reiser, Literaturnye kruzhki i salony (Leningrad, 1929), 80, 81.

${ }^{32}$ Victor Erlich, Russian Formalism: History, Doctrine (The Hague, 1965), 126.

${ }^{33}$ Boris Eikhenbaum, Moi vremennik: Slovesnost', nauka, kritika, smes' (Leningrad, 1929), 51.
} 
collective activity. ${ }^{34}$ The tension between the ideal of collective cultural practice and the persisting centrifugal power toward intellectual exchange in smaller, self-defining circles was reflected in the debates around the workers' clubs in the late 1920s that kept on defending the small group as a significant unit in the emerging socialist culture. ${ }^{35}$

The debate between Sinyavsky and Iurii Mal'tsev over the political dimension of "intermediate (promezhutochnaia) literature" can serve as a textbook example of how aesthetic and political arguments are intertwined with the social organization of the literary field. In "On Literary Criticism," Sinyavsky brings together the need for literary criticism and the value of discussing politically unengaged Soviet literature. ${ }^{36}$ This so-called "intermediate literature" was published officially in the Soviet Union, but positioned itself as neutral toward official poetics and politics; examples were Iurii Trifonov or Vasilii Shukshin. Sinyavsky's article is a polemical reaction to Mal'tsev's "Intermediate Literature and the Criterion of Authenticity." Being apolitical, Mal'tsev had argued, equals tacit agreement with the dominant ideology and deceptively creates a notion of security. Under the totalitarian condition of persistently politicized life, "ignoring this means pursuing a politics that is convenient for the ones in power."${ }^{37}$

If the strengths of the third-wave emigration are its understanding of Soviet culture and lasting personal connections to the homeland, Sinyavsky argues, these ties could be productively strengthened even more through the very institution of literary criticism"not pronouncing condemnation and judgment, but a more serious, ramified, and at the same time concrete review of literary occurrences on both sides of the barriers built by the state. ${ }^{\prime 38}$ Sinyavsky's openness toward the intermediate literature would mirror Sintaksis's alleged preparedness to open discourse on Soviet culture in more than a completely dismissive way, while Mal'tsev's position could be seen in line with Kontinent's strict antiSoviet stance.

The procedural practice of aesthetic taste defended by Sinyavsky resembles the discourse of the salon, the clash between the two positions - in other words, the competitive development of salons as prototypical political parties. In his response, printed in the letters section of Sintaksis, Mal'tsev presents an example of well-argued and competitive debates between two intellectuals representing their respective institutions, defending himself against Sinyavsky's criticism that, as he says, for the most part missed its target. ${ }^{39}$

With the move from the salon to the journal, larger numbers of authors are included than could ever be accommodated by the intimate conditions of the salon. Nevertheless, the difference between the salon-style journal and the model of the Soviet mass journal should be traceable on the journals' social constitution on a larger scale. Evening out competing voices, including at times even dissident ones - as shown in the example of

\footnotetext{
${ }^{34}$ Varvara Stepanova, "Rabochii Klub (Konstruktivist A. M. Rodchenko)," in Formal'nyi metod: Antologiia russkogo modernizma, ed. Sergei Ushakin, vol. 2, Materialy (Ekaterinburg, 2016), 883.

${ }^{35}$ For the debate around the workers' club as a space and its intellectual functions see Selim Khan-Magomedov, Arkhitektura sovetskogo avangarda, vol. 2, Sotsial'nye problemy (Moscow, 1996), $534 \mathrm{ff}$.

${ }^{36}$ Sintaksis 10 (1982).

${ }^{37}$ Kontinent 25 (1980): 300.

${ }^{38}$ Sintaksis 10 (1982): 155.

${ }^{39}$ Sintaksis 11 (1983): 212-15.
} 
Rozanova's successful publication in Dekorativnoe iskusstvo after Sinyavsky's arrest - the professionally managed mass journal can rely on a larger circle of authors. Moreover, the coordination of a huge body of authors is of central importance to its ability to forcefully argue its ideological positions. The salon-journal, on the other hand, would rely on a small circle of authors, providing the intimacy for personal debate.

One could therefore expect to see, in a comparative analysis of the bibliographical data, that Sintaksis would have a larger number of recurring authors that form a narrower community, while Kontinent would incorporate a significant number of contributors who appeared less frequently on its pages. After all, Maximov's own insistence that he would publish Sinyavsky at any time confirms this idea. As opposed as he may have been to Sinyavsky's positions, he too may very well have been aware that sporadic publications by Sinyavsky would not have stuck out among the large number of authors featured by the journal.

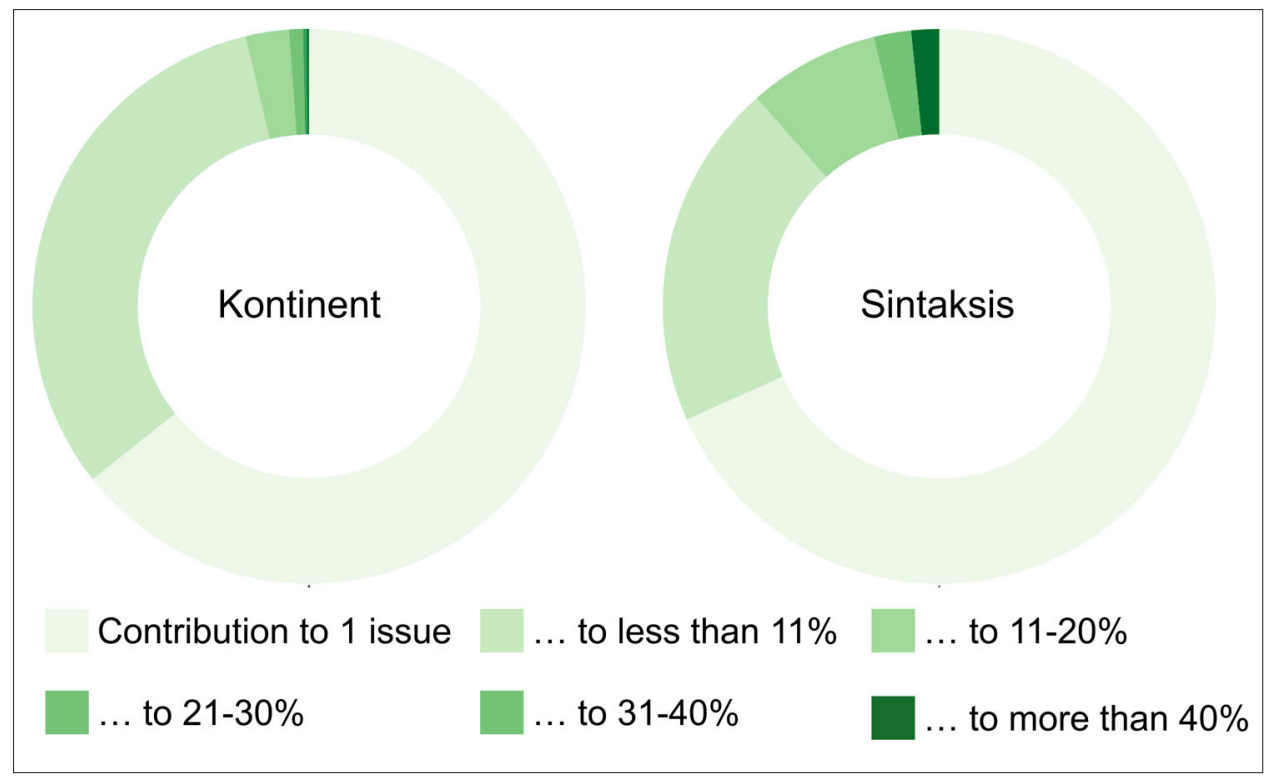

FIG. 5 Types of authors constituting the pool of contributors to Kontinent and Sintaksis between 1974 (1978 for Sintaksis) and 1992.

The majority of contributions to both journals is by one-time authors and contributors who appeared in less than 10 percent of the issues, as represented by the two largest sections of the respective diagrams.

Quantitative evaluation of the data in figure 5 divides the authors of Sintaksis and Kontinent into six groups: those who only ever appeared once in the journal, those who appeared in ten percent or less of all issues of the respective journal, those who appeared in 11-20 percent, 21-30 percent, 31-40 percent, and more than 40 percent of the respective journal's issues. ${ }^{40}$

${ }^{40}$ For the purpose of this evaluation of the journals' metadata, pseudonyms were treated as separate persons. Andrei Sinyavsky and Abram Tertz are the most obvious incidents of this perception that can be justified with the persistent staging of the two literary personas as an integral component of the literary tactics of the author 
Surprisingly, the percentage of unique contributors among all authors is similar in both journals; it is even slightly larger in Sintaksis, where 68 percent of all authors were only ever published once, while in Kontinent 64 percent of the authors were one-time contributors. Authors appearing more than once but in less than 10 percent of the issues are a relatively stronger group in the pool of contributors of Kontinent. The last four groups, those published in more than 10 percent of the issues, are significantly larger for Sintaksis, amounting to 12 percent of all of its authors, as opposed to 4 percent in Kontinent.

Kontinent can thus be understood as a traditional mass journal, accommodating large numbers of replaceable authors around a very small group of recurring authors who act as the lead figures commonly associated with the journal and its key positions. Sintaksis, however, shows an unexpectedly higher tendency toward the same kind of reliance on contributions by authors that do not have a persisting affiliation with the journal than would be expected from a journal that mimics the intimacy of the salon. At the same time, the leading group, contributors to more than 40 percent of the issues is largely overrepresented. ${ }^{41}$

Following the model of the professionalized journal, Sintaksis is confronted with a reality of publishing — namely, the necessity of disposable authors to fill the pages of every issue. The promise of a journal with a unique and recognizable face is thus fulfilled only to a certain extent, compensating for this fact through the dominance of one very powerful core group of authors. Rozanova thereby closely engages with the strategies of the dominant forces of the émigré publishing landscape in a tactic that partially incorporates Kontinent's standard strategy of journal-making. In the words of Michel de Certeau, "the place of a tactic belongs to the other. A tactic insinuates itself into the other's place fragmentarily, without taking it over in its entirety, without being able to keep it at a distance." ${ }^{\prime 42}$ Sintaksis's tactic appropriates and modifies the ways Kontinent organizes its social environment and needs to be understood as part of Sinyavsky's artistic project.

Catherine Theimer Nepomnyashchy has traced this artistic tactic in the writing of Sinyavsky's alter ego, Abram Tertz, as the quest for "aggravated reader response, not only to the works themselves but to the circumstances of their publication." ${ }^{43}$ This holds true as

(Catherine Theimer Nepomnyashchy, Abram Tertz and the Poetics of Crime [New Haven, 1995]). Other cases like the literary pseudonyms of Leonid Sedov, L. Ladov, and Leon Rzhevskii stand witness to the mode of dissident literary production. Here, the anonymity originally was a guarantor for security from criminal prosecution, but quickly developed into a game of authorial masks. This introduced centrifugal forces into the formation of intellectual communities that could not be discerned from anyone not belonging to a very narrow social circle. For many readers of the journals, these multiple identities of individual authors must have gone unnoticed.

${ }^{41}$ The most common contributors in Sintaksis are Andrei Sinyavsky - 73 percent (of all issues); Zinovy Zinik - 48 percent; and Igor' Pomerantsev - 45 percent. All of them play an important role in the development of Sintaksis's strategies of cultural life in the Soviet Union on the Seine.

${ }^{42}$ Michel de Certeau, The Practice of Everyday Life, trans. Steven Rendall (Berkeley, 1984), xix.

${ }^{43}$ Nepomnyashchy, Abram Tertz and the Poetics of Crime, 2. Of course, the initial discovery of the real identity of Abram Tertz by Soviet authorities was much more serious than that. Sinyavsky had been secretly publishing texts in the West since the late 1950s-such as his short novel The Trial Begins and his polemical exposé of Soviet literature What Is Socialist Realism? He was arrested in late 1965 and sentenced to seven years in prison camp for anti-Soviet agitation. This show trial received much attention both internationally and among the Soviet intelligentsia and can be considered one of the landmark events of the end of the Khrushchev Thaw. 
much for his fiction as for his "fantastic literary scholarship," a provocation of the academy, but it can ultimately also be traced in the ways Rozanova subverts the rules of journalmaking among the Russian emigration. ${ }^{44}$

\section{THE SYNTAX OF SUBVERSION}

Surprisingly, the climactic subtitle of Sintaksis-Journalism, Criticism, Polemics - does not mention literature, although the journal did also feature literary texts. Yet to understand Sintaksis fully it must be viewed as an artistic project that appropriates the model of the thick journal and claims for itself the institutional functions of the salon only in order to creatively subvert them. This section aims to unveil the very tactics of subversion allowing Rozanova to address the restrictive features that appear to be inevitably attached to the thick journal as a cultural form.

In the words of de Certeau, Sintaksis's tactic can be described as a subversive use of a predetermined repertoire of cultural forms, an unavoidable appropriation rather than the avoidance of a model of "products imposed by a dominant economic order"-namely, of the Soviet thick journal transplanted to the West by Maximov and facilitated by Springer. ${ }^{45}$ Sintaksis contributes to the persistence of the Soviet model of the thick journal, which had been repurposed by Maximov with a different ideological mission. But paradoxically, Rozanova's tactic also opposes this model at the same time (fig. 6).
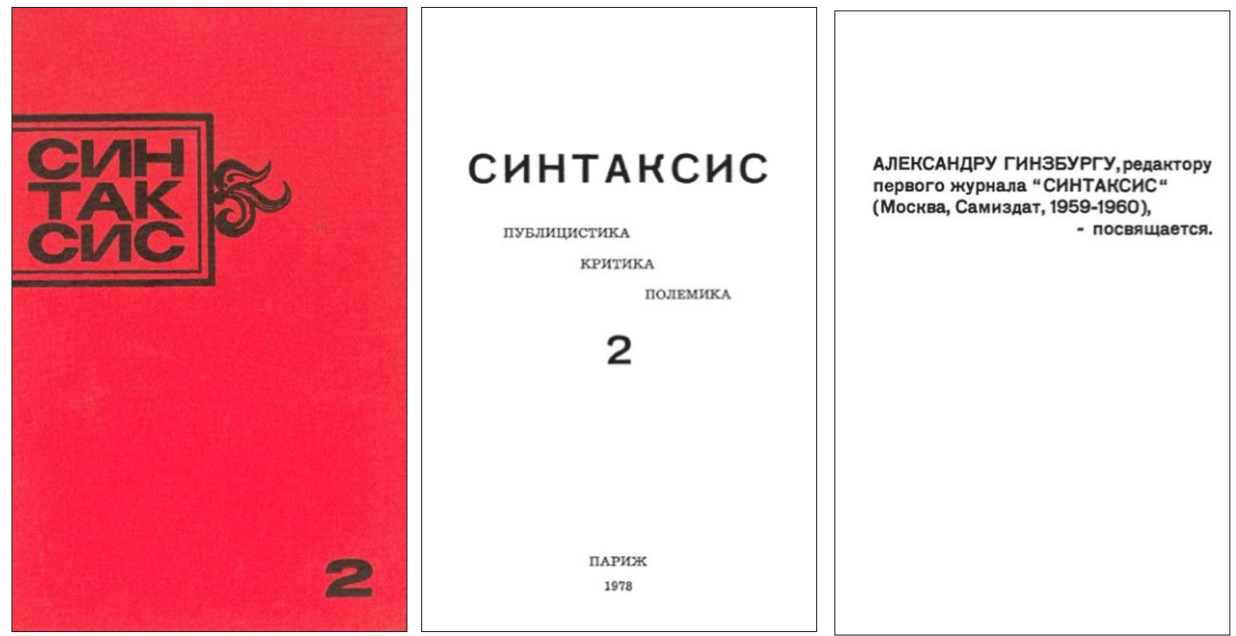

FIG. 6 Cover, title, and dedication pages of Sintaksis 2 (1978).

Rozanova's tactic is the rearrangement and synthesis of cultural forms. In the first issue, the title Sintaksis and a dedication to Aleksandr Ginzburg establish a genealogical connection to another mode of artistic production. They reference the eponymous Soviet samizdat almanac, three issues of which Ginzburg published between 1959 and his arrest 
in $1960 .{ }^{46}$ Moreover, instead of an editorial foreword, the first issue of Sintaksis opens with a five-page essay by Natal'ia Rubinshtein that reminisces about Ginzburg's almanac, creating a nostalgic mood: "In Russia we read [the almanac] for the first time in 1959-60. Reading it today in Paris is just like returning to one's parents' house or remembering one's first love." Compared to the pompous forewords to the inaugural issue of Kontinent, the essay appears innocent. Not calling for any action, it celebrates the apolitical: "Sintaksis [the almanac] did not fight the Soviet state, but the Soviet state immediately came to fight Sintaksis, opposing its three hundred issues through Komsomol'skaia pravda, which had a print run in the millions." ${ }^{27}$ The almanac Sintaksis is presented as an exclusively aesthetical project organized by a circle of friends, a David that was only retroactively promoted to a political dissident by the ideological Goliath of the Soviet state.

The samizdat almanac is nostalgically conjured for its community-building power in a way that may seem somewhat counterintuitive to the common patterns of late Soviet émigré nostalgia. Nostalgia for the prerevolutionary homeland is commonly observed in the writings of the first generation of Russian emigrants, but, as Olga Matich observes, it is less prevalent in the second or third wave. ${ }^{48}$ After all, the intellectuals concerned here had fled the Soviet state. Nevertheless, the memory of Soviet life retains a positive affective component.

But the connection between émigré publications and Soviet samizdat is also a very manifest one. The émigré press played a pivotal role in the "transnational diffusion" of samizdat and tamizdat. ${ }^{49}$ Not only did the journals contribute to securing the publication in the West of uncensored texts from the Soviet Union; they also returned the texts to the Soviet Union, when printed issues were smuggled back into the country. ${ }^{50}$ The reference of the title "Sintaksis" established an affective tie, as underlined by Rubinshtein's essay; it points to the rootedness of the journal in a specific economy of texts between samizdat and tamizdat; and finally, it can also be read as a reference to a new kind of dissident status of the journal itself.

Unlike Kontinent, Sintaksis was not supported by a publishing house or an editorial office, but produced semiprofessionally in the family home of Rozanova and Sinyavsky. The journal's social function may not be fully dictated by its materiality in the way that characterizes true samizdat documents, where circulation and recopying of texts facilitated a special community of social ties governed by an economy of a kind of gift exchange. ${ }^{51}$

\footnotetext{
${ }^{46}$ In 1965 the content of the Soviet samizdat almanac Sintaksis was published in the journal Grani (Frankfurt/ Main, Germany).

${ }^{47}$ Sintaksis 1 (1978): 3, 5.

${ }^{48}$ Ol'ga Matich, "Literatura Tret'ei volny: Granitsy, ideologiia, iazyk," Novoe literaturnoe obozrenie 1014, no. 3, http://magazines.russ.ru/nlo/2014/3 (last accessed February 4, 2018).

${ }^{49}$ Kind-Kovacs and Labov, Samizdat, Tamizdat, and Beyond, xx.

${ }^{50}$ It remains unclear how far this cultural exchange reached beyond the metropolitan centers of European Russia and narrow circles of the progressive intelligentsia, although one author reported around five hundred issues in circulation that reach hundreds or even thousands of readers in Moscow. See Anatolii Kopeikin, "Dolgota i shirota 'Kontinenta': Zhurnal chitaiut u nas na rodine," Russkaia mysl' (July 12, 1984). While issues of Sintaksis and Kontinent are scarce in Russian library collections, more than one hundred Western research libraries collected Sintaksis, the print run of which has never been documented but probably did not exceed a few hundred. This testifies to the journal's importance among émigrés and Slavists in the West.

${ }^{51}$ Ann Komaromi, "Samizdat as Extra-Gutenberg Phenomenon," Poetics Today 29:4 (2008): 656.
} 
However, this positioning as a dissident cultural project with its distinct features of dilettante publishing took up a key function in Sintaksis's editorial tactics.

Rozanova's periodical needed to counteract a discursive dependency on a dominant other in the émigré field. ${ }^{52}$ The self-fashioning as the victim of this other that Rozanova performed at the Los Angeles conference in 1981 already displays a pattern of self-subjection. The digitized corpus of the two journals allows us to trace this kind of dependency in the text of the journal itself-across fifteen years of the two periodicals' coexistence. Based on the idealistically indistinct ("in alphabetical order") advertisement of other émigré periodicals in Sintaksis, one might expect that the journal would engage with others in a relatively balanced way: as one actor within a pluralist network of numerous equal publications. The quantitative evaluation of the complete corpus of the journal suggests otherwise. The idea of a dominant other persists in the form of a heightened dependence on Kontinent, continuing what for the Soviet context has been called the "terrifying mimicry of samizdat."

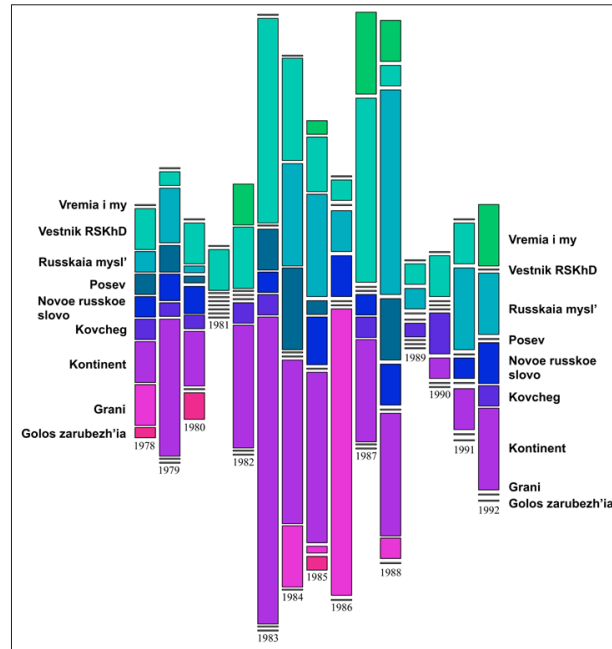

FIG. 7 Journals most frequently mentioned in Sintaksis by year.

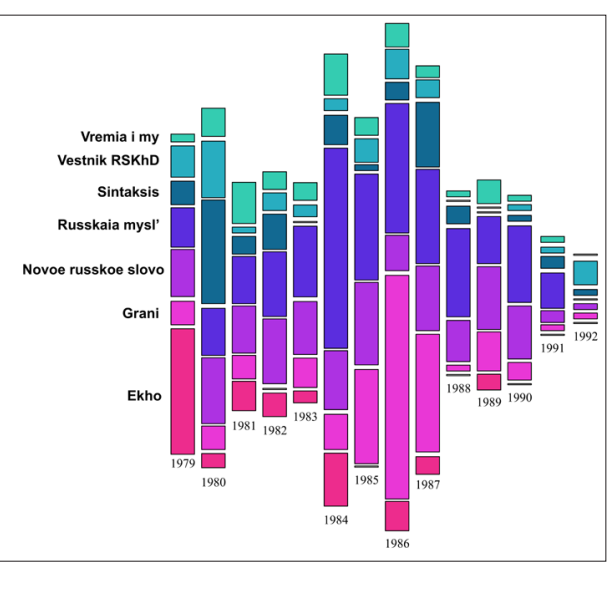

FIG. 8 Journals most frequently mentioned in Kontinent by year.

Since the number of issues in every year varies, these quantitative evaluations show the average number of references to other publications per issue for every given year. For instance, two issues of Sintaksis were published in 1978. Kontinent was mentioned on average twice per issue, just like Grani and Vestnik RSKhD.
toward the end of the 1980 s.

As figure 7 shows, Kontinent figures most prominently among the journals that are discussed on the pages of Sintaksis. While other periodicals may be more visible in certain years, such as Grani in 1986, the persistent presence of Maximov's publication, especially in the first half of the 1980s, is striking. This can confirm the dependency hypothesis; Sintaksis relies strongly on an ongoing and explicit engagement with Kontinent - be it in

\footnotetext{
${ }^{52}$ For the Soviet context, this kind of dependency relation between dissident and official discourse has been described as the "terrifying mimicry of the samizdat text, its shocking (speak)ability to reproduce the discourse of the dominant without merging with it, [which] is a product of the same structural nature, albeit in a different form." See Serguei Oushakine, "The Terrifying Mimicry of Samizdat," Public Culture 13:2 (2001): 204.
} 
positive or (most often) negative terms. If this dependency does indeed represent the "terrifying mimicry" of dissident culture, one may assume that this emphasis is not mutual. The evaluation of the full text of Kontinent confirms this notion (fig. 8).

On the pages of Kontinent, Rozanova's journal figures merely as one among many other publications. Its visibility as an oppositional voice is thereby decreased. While the publication may enjoy moments of prominence, these moments are singular; much like dissident voices only sporadically found scandalous attention in the Soviet press. Kontinent does thus not reciprocate the wave of attention it garnered in Sintaksis in the early 1980s. Interestingly, the overall decrease in interaction with the larger network of émigré periodicals toward the late 1980s can be traced in both journals.

In other words, there is significant presence of Kontinent in Sintaksis, but the opposite is not the case. As I will show in the following, Sintaksis faced this dependency by subjecting it to a number of modulations. Rozanova and Sinyavsky thus incorporated the realities of an existing model of cultural production, in the words of de Certeau, "not by rejecting or altering them, but by using them with respect to ends and references foreign to the system they had no choice but to accept." ${ }^{33}$

The repertoire of cultural forms that Rozanova appropriates resembles a repertoire of linguistic signs, while her practice of publishing Sintaksis is a distinct kind of speech, an arrangement of the signs that can subvert the very system of the language. From that perspective, it is no coincidence that the journal is titled just Sintaksis. Not only does it explicitly counter the pretension of other titles such as Kontinent, which it mimics phonetically in the three syllables SIN-TAK-SIS that seem to mirror KON-TI-NENT. The same applies for other formal features of Kontinent that are repeated - the format of slightly smaller than 5" x 7" supposedly introduced by Kontinent to make it easier to bring issues to the Soviet Union. However, the covers of Sintaksis are monochromatic, rejecting the pathos that the pictures of influential persons on the cover of Maximov's journal bear. The front matter of Rozanova's journal repeats another common feature of the thick journal - an editorial board, here called a "League of Supporters."

In all these appropriations, the title of the publication is programmatic. If syntax is a set of rules governing the arrangement of linguistic signs to form an utterance and convey meanings, the syntax of Sintaksis can be found in the ways that Rozanova arranges formal features, texts, and names. By introducing, for instance, her own editorial board and calling it a League of Supporters, she exposes them as politically lacking concrete influence when it comes to editorial work.

The syntax of the League of Supporters translates directly into a syntax of how Rozanova organizes and antagonizes the literary field around herself, as illustrated by a 1986 incident where Vasily Aksyonov published a protest note attacking Rozanova in Russkaia mysl'. Aksyonov, who had left the Soviet Union in 1980 and subsequently was stripped of his Soviet citizenship, was himself experienced in the practice of the thick journal. Not only had he gained literary fame for his prose during the Thaw, he also had served for several years on the editorial board of Iunost', one of the most successful literary magazines of the early 1960s. In his open letter, he recollects an afternoon tea with a group of writers

${ }^{53}$ Certeau, Practice of Everyday Life, xiii. 
including Sinyavsky and Rozanova, who pressed him about his affiliation with Kontinent to the point that Aksyonov allegedly agreed to join Rozanova's list as well. Accordingly, she printed his name in her League of Supporters and, in a later issue, ran a reprint of Aksyonov's protest note from Russkaia mysl' next to her "transcript" of the abovementioned gathering.

Haunting the authors, Rozanova became at times an editorial stalker with an insatiable desire for the clarification of social relations that, according to her, constitute Russian literature. ${ }^{54}$ While these negotiations are strongly political in nature, seemingly reminiscent of the omnipresent politicized aesthetics of dissident and émigré literature, at a second glance these incidents point in the opposite direction. Sintaksis aestheticizes politics. It artfully exposes, destabilizes, and reconstructs authorial identities and textual stability.

This highly personalized and emotionalized social syntax runs throughout the journal, as exemplified in an early debate about anti-Semitism that spanned several issues in between 1978 and 1980. Published under the headline "Without Telling Names," an interview with an anonymous Russian anti-Semite displayed a range of hateful clichés, conspiracy theories, and nationalistic chauvinism. Four issues later Sintaksis carried a letter in response, in which the reader, having failed to realize the irony of the interview publication, expresses her agreement with the anti-Semitic rant. ${ }^{55}$ Rozanova's treatment of this absurd letter sets a precedent for the approach to contrary positions. Not deserving of privacy, the reader's address is published along with the letter. Two responses, supposedly by Prince Andrei Volkonskii and Prince Vladimir Trubetskoi, published in Sintaksis in 1980, paid like with like. Not invested in argumentatively disarming the opponent, they turn to personal exposure and ridicule. ${ }^{56}$ The debate that spans several issues appears actively curated. The journal as a participatory medium, where readers' letters are taken at face value, is used to perform a distinct mode of debate.

At times, this kind of personal polemics is met with rejection even by Rozanova's League of Supporters. A parody of a conversation between Maximov and the managing editor of Kontinent, Violetta Iverni, which originally was published in Kontinent in 1980, depicts Maximov as an megalomaniac egotist and Iverni as a nymphomaniacal sycophant. Rozanova's parody prompted the immediate protest of Tomas Venclova, whose letter was printed in the following issue. While many shortcomings of Maximov and Kontinent deserve to be criticized, he points out, a certain form needs to be maintained: "Of course, one can print anything. But not everywhere. In a serious journal such texts are unsuitable. They are simply unworthy. ${ }^{" 57}$ The response is an interesting reminder of a certain protocol of

\footnotetext{
${ }^{54}$ The aphoristic expression "Russian literature in general is a constant clarification of social relations" is commonly ascribed to Rozanova. See Vladimir Novikov, "Filologicheskii roman: Staryi novyi zhanr na iskhode stoletiia," Novyi mir, 1999, no. 10:193-205.

${ }^{55}$ The reader claims to have uncovered a major conspiracy, "since after so many years of silence among cultured Russians an insight seems to trickle down in their minds - the insight of who those Jews are and how much evil they brought and are bringing to the world" (Sintaksis 6 [1980]: 157).

${ }^{56} \mathrm{As}$ one letter states, "it has been proven that everyone who really wants to can easily deceive the Russian people, the stupidity of whom is immeasurable—as has been shown by your letter" (Sintaksis 8 [1980]: 189).

${ }^{57}$ Sintaksis 12 (1984): 206.
} 
journalistic ethics - a filtering mechanism that is counter to Rozanova's practice of editorial scandal, of which the angry responses printed in the journal are an essential component.

Closely linked to this social arrangement is the arrangement of texts that are immediately (and legally) connected to their authors. Sintaksis took the freedom to print copyrighted texts, publishing for instance a rather liberal and abridged translation of Nabokov under the title "Imaginary Interview with Vladimir Nabokov." "A "Authored" by Zinovii Zinik, the piece promptly provoked a letter of protest from Vera Nabokova, which Sintaksis published along with an apologetic note from the editor. ${ }^{59}$ However, the incident does not end on this note, but rather moves toward further provocation. Another response from a certain Baron Z. von Gluzberg, a pseudonym of Zinik, ridicules Nabokov's widow and defender of the author's estate. Von Gluzberg ironically chimes in with her pretensions to Zinik and concludes by polemically pointing out another incident of copyright infringement-namely, an unauthorized translation of Nabokov's English-language Eugene Onegin in the Soviet Union by "a certain Alexander Pushkin." 60

The disinterest in intellectual property and authorship can be traced back to the Soviet context, where in the system of samizdat anonymity served as a security mechanism and where official publishing, especially of translations, was governed by relative obliviousness toward author rights until the country joined the Universal Copyright Convention in 1973. The disposition of Soviet authors toward this kind of freedom drastically changes with the moment of emigration, where authors found themselves facing a literary environment that is organized economically rather than politically. ${ }^{61}$ Accordingly, it was acceptable for Grani to publish the Russia-based poets of the original Sintaksis, but it unacceptable for the Parisbased Sintaksis to publish Nabokov.

Rozanova's publishing practice becomes therefore an organized clash between these two standards - the Soviet dissident as well as official habitus of neglecting questions of intellectual property, and the Western persistence on their strict observation. In other words, Sintaksis plays with what Bourdieu has named the hysteresis effect, where "practices are always liable to incur negative sanctions when the environment with which they are actually confronted is too distant from that to which they are objectively fitted." ${ }^{62}$ For Rozanova, the hysteresis effect functions as a mode of provocation that her journal celebrates.

It is ultimately the domestic mode of production and the limited access to resourcesin other words, the self-fashioning as something reminiscent of a samizdat publicationthat become an inspiration and an excuse for this practice. ${ }^{63}$ They allowed Rozanova to corrupt the syntax of the professional journal-at times quite literally. Typesetting errors in the journal were semantically productive and became subject to vehement objection-

\footnotetext{
${ }^{58}$ Sintaksis 15 (1985).

${ }^{59}$ Sintaksis 18 (1987).

${ }^{60}$ Sintaksis 20 (1987): 207.

${ }^{61}$ Solzhenitsyn's struggle to regain control over his intellectual property upon his arrival with the help of Swiss lawyers can be considered as a paradigmatic example of this shift. He writes about it at great length in his memoir. See his Sobranie sochinenii v tridtsati tomakh, vol. 29, Udogilo zernyshko promezh dvukh zhernovov (Moscow, 2006.).

${ }^{62}$ Bourdieu, Rules of Art, 78.

${ }^{63}$ The tendency of Soviet samizdat to priviledge "epistemological instability" over the "rock-hard truth of the text" thus resurfaces in emigration (Komaromi, "Samizdat as Extra-Gutenberg Phenomenon," 632).
} 
this time in letters from two frequent contributors: Pomerantsev and, again, Zinik. Errors, Rozanova responds, are inevitable in a journal that is the project of a community of human beings: "A journal is a collective thing. Everyone contributes what they can: the authora text, the editor-his own ingredients, the typesetter - typos and other mischief (khuliganku), the proofreader-mistakes. ${ }^{964}$ Of course, this editorial team is a fictitious rendering of Rozanova's solo-project, for all the roles mentioned are fulfilled by herself. But the representation of this kind of a social group is of great importance for the journal's self-presentation as a community.

Rozanova's repetition of the errors that the authors had complained about also brings to the fore the ability of unreliable texts to subvert. She concedes that Sinyavsky's first name is not Andei, but Andrei. Solzhenitsyn and Dostoevsky, she admits, are titans (titany) and not in the least tyrants (tirany), and the Russian emigration, she corrects her earlier mistake, is bilingual (dvuiazychnyi) rather than double-tongued (dvuiazykii). Of course, the explicit repetition of every "typesetting slip" reinforces the wrong version rather than the corrected one.

The syntax of Sintaksis artfully destabilizes the landscape of émigré literary culture through its persistent ambivalence between play and serious, between liberal and authoritarian statements, between respect and disrespect. After all, it was fittingly over the adjective bilingual (dvuiazychnyi), and its misrepresentation as two-tongued (dvuiazykii), that Zinik complained to Rozanova in his letter about Sintaksis's unprofessional editing work.

\section{CONCLUSION}

In the 1986 interview quoted in the epigraph, Rozanova characterized the world of thirdwave emigrants as an inevitable reenactment of their former Soviet environment. If only they could, they would have rebuilt in the West the infamous Lubyanka prison associated with Soviet state terror. In Rozanova's hyperbolic statement, we can discern the third wave as both perpetual agents and perpetual victims of repression. At the same time, it implies an atmosphere of mutual hostility and aggression in what would then appear not merely as a new Moscow, but a new Soviet Union on the Seine. But it is misleading to think of the sovietization of this new social environment merely in terms of an ideological conflict with sharp conceptual boundaries, as a fight between democratic pluralism and totalitarian dogmatism.

The Soviet habitus of the third-wave emigration does not merely bring forth a binary ideological conflict on the level of political or aesthetic argument; it determines the very structures of cultural production in the West and the social life associated with it. As one of its major cultural products and social institutions at the same time, the thick journal is a unique component of the life of this generation of emigrants, showing the Soviet-born structures at work. The holistic view of the journal necessary for this observation is made possible by the approach of periodical studies and the analysis of the journals through their bibliographical data. 
These data provide arguments that can challenge the notion of the Soviet Union on the Seine as a binary conflict between two ideologies. They also stimulate new readings of the journals that focus on the prevalence of strategies for the organization and social function of mass journals in the tradition of Lenin, on the one hand, and on subversive tactics developed and fine-tuned in response to this structural model, on the other. In Sintaksis, a journal that does not carry the designation "literary" in its subtitle, these tactics are still very much a product of artistic practices that appropriate models of literary culture - the literary salon/club, samizdat, and the professional journal — in a synthetic way. Rozanova's journal subverts this repertoire of cultural forms by subjecting them to her own syntax of journal-making.

What unites Kontinent and Sintaksis is their reliance on ideal claims about journals that do not hold up to closer examination of the editorial reality of the journals - most centrally, the idea of independence and freedom in emigration. However, it is not the restrictive policy of editors that limit this independence, but the impossibility of freeing oneself from a Soviet heritage that governs all cultural production, even in the West. The actors of this culture may be unaware of these limitations, but it is also with great intuition that they subvert them, as shown in the case of Sintaksis.

It is telling that both journals remain reliant on the Soviet metropolis. As Soviet cultural institutions are restructured or retired after Gorbachev's perestroika and the disintegration of the Soviet Union, they too face an existential crisis. Kontinent has reacted by moving its editorial office to Moscow and becoming an institution rooted in post-Soviet Russian culture, while Sintaksis has slowly faded, with only four more issues published between 1994 and 2001. 